\title{
The Research on Chinese College English Teaching Effects
}

\author{
$\mathrm{Xu}$ Yiqun \\ Foreign Language Department \\ Jilin Business and Technology College \\ Changchun, China \\ 182076127@qq.com
}

\begin{abstract}
Firstly, it analyzes the status of Chinese college English teaching. According to the 2014 global adults' English proficiency report, the average of Chinese adults' English level is low. The English level of our college graduates can't meet national internationalization demand. Secondly, aiming at existing questions, some solutions are put out. The first is developing ESP(English for Special Purpose) and the second is building teaching system which meets international needs and faces working abilities. Then the concept of ESP is given. The ESP curriculum can be divided into two main parts: EAP(English for Academic Purpose) and EOP(English for Occupational purpose). At last, it summarizes the future development of college English teaching. ESP teaching and general English teaching will be a trend of our future English teaching.
\end{abstract}

\section{Keywords—college English teaching; ESP; general English}

\section{The Status of Chinese College ENGlish TeACHING}

\section{A. The status of Chinese adults' English level}

2014 global adults' English proficiency report was published by international EF education in November, 2014. The investigation result shows that the average of Chinese adults' English level is 50.15 points, falls behind South Korea(53.62), Japan(52.88), Hongkong(52.50), Taiwan(52.56), even Vietnam(51.57), and is low proficiency. The statistic also shows the age of highest Chinese adults' English level is from 18 years old to 24 years old. And English level differentiates after 24 years old. But the falling of Asian adults' English level appears after 35 years old. In addition, the English level of employees of Chinese companies is also lower than the world's average. For example, in IT field, Chinese employees' English level(46) is much lower than Vietnam(62), Taiwan(58), South Korea(55) and Japan(54). Similarly, the English level of employees in finance and manufacture is lower than global average[1].

\section{B. The status of the demands of our college graduates English ability}

The English level of our college graduates can't meet national internationalization demand. Since this century, China has transferred from national country to international country. In recent years, China's economic globalization is becoming more and more apparent. On one hand, more and more international enterprises and organizations are located in China; On the other hand, more and more Chinese enterprises go abroad to do international acquisitions and invest. Higher Education Department leader Zhang Yaoxue did an investigation, finding that Indian software employees are far less than China's. But their export is 10 billion dollars, which is five times that of China. "The main problem is that the English application ability of the majority of our college graduates is bad and it is difficult to adapt to the needs of international developing in information field. According to statistics, the amount of Chinese people working overseas at present has been over three million. But the people who can use foreign language proficiently to negotiate with foreign clients and sign contracts are very few, even in Shanghai where the average of employees' English level is better than other places[1].

Analysis of the questions concerning identification of students' basic aims, language skills and language activities in learning English indicates that students mostly needed to learn English for future academic studies and for job purposes. The majority of students reported that they wanted to be successful in the courses taught in English, to find a good job after graduation, to pursue future studies, and to use course materials in their majors as shown in Table I. Only a small group of students learnt English since it was compulsory to attend the preparatory program or they wanted to go abroad for work purposes.

International famous scholar Spolsky thinks that the contribution of third world scientists to their subjects has surpassed $30 \%$, but the published thesis have not reached $5 \%$ of international topic professional journals. It has much to do with low academic level. IET is the world topic professional academic institute in engineer technology field. According to the introduction of IET Chinese publication director Govan, the rate of submitted thesis and eventually published thesis by Chinese in IET is $16.5 \%$, far falling behind our neighbors Japan and South Korea, of which the latter published rate gets $25.2 \%$. The total of thesis published in SSCI and A\&HCI by Japanese universities is three times that of Chinese mainland universities. Tsinghua University original foreign language director Sun Fuchu criticizes the graduates of Tsinghua University: After having passed CET4/6, the graduates can't read English journals and write English thesis. According to these facts, the shortage of English application ability of our 
college graduates has seriously restricted the development and realizing of Chinese international strategy requirements.

TABLE I. STUDENTS’ PURPOSES FOR LEARNING ENGLISH

\begin{tabular}{|c|c|}
\hline Purposes for learning English & Frequency \\
\hline To be successful in the courses taught in English & $25.8 \%$ \\
\hline To find a good job in the future & $22.7 \%$ \\
\hline For future studies & $21.6 \%$ \\
\hline Because attending the language program is compulsory & $15.5 \%$ \\
\hline To make use of materials in their field of study & $10.3 \%$ \\
\hline To go abroad and work & $4.1 \%$ \\
\hline
\end{tabular}

\section{The EXISTING Questions of CHINESE COLLEGE ENGLISH} TEACHING AND SOLUTIONS

\section{A. Existing questions}

Jing Shenghua(1999) thought that college English teaching is a bottle of warm water. The source of problem is that the choosing of contents of Chinese non-English major college English textbooks focuses on literature, politics, but ignores current practical contents. Dai weidong(2001) thought that the foreign texts of primary education and high education are separated, the contents are repeated, teaching are badly linked, teachers foundation power is not enough, teaching scale develops too fast. The result is wasting time and low efficiency of foreign language teaching. Zhang Yaoxue(2002) thought that public language teaching goal emphasizing teaching, is the main factor of the phenomenon. Wu Qidi(2004) summarized the existing questions of college English teaching represent of education department:(1) The teaching ideas are relatively falling behind. For example, the focus on the developing of foreign language comprehensive application abilities is not enough. (2) Teaching model and teaching method are relatively single and old, such as the classroom teaching mode of teachers' focusing on teaching and students' focusing on listening. (3) The whole level of teachers is going to be improved. (4) Unlinked to primary and junior teaching. The result is wasting time of the whole language learning, low efficiency and students' boring emotion. (5) Teaching according to texts is still existed, pursing the passing rate of CET4/6.

If it is the phenomenon before reform, what about the phenomenon after reform. Cheng Xiaotang and Kangyan(2012) display the seven questions of college English teaching:(1) The teaching goal is not clear. The description of teaching goals of published college teaching outline is indirect. (2) Teaching requirements and testing requirements are mixed. The result is to break regular teaching and help to increase exam-oriented education phenomenon. (3) There has no efficiency links between college English teaching and high school English teaching. (4) Too much emphasize on the tool of English. (5) Too much emphasize on the teaching of knowledge and ignore the developments of abilities. (6) The theoretical research and technology research of compilations of teaching materials are very poor. (7) Foreign language teachers lack the learning of special foreign language educational theory, and most are teaching by experience. Shu Dingfang and Chen Suyan(2012)thought that there are nine questions existing in college English teaching: (1) position and education goals are not clear; (2) Demand analysis is lacked; (3)On the arrangement of curriculum and the training of listening, speaking, reading and writing skills, the curriculum is designed unscientific; (4) As the work of teachers is overloaded and research power is limited, teaching staff is difficult to adjust to new requirements; (5) Teaching sources including texts can't meet students' real needs; (6) Classroom teaching uses teachers-centered intensive reading and PPT teaching, and exam-oriented teaching is still existed; (7) The learning attitude and motivation of students are not good; (8) students are lack of good learning methods; (9) Foreign language teaching evaluation lacks scientific[2].

\section{B. Solutions}

Cai Jigang(2004) puts forward that therefore we still have to persist the post and pre relationship of primary English teaching and ESP teaching. Curriculum is practical. To the students whose English are not good, they had better learn primary English. But to the students whose English are good, they had better learn ESP curriculum. As for school, to general colleges, there can be more primary English teaching. ESP can be taken as an elective course. Zhang Yaoxue(2002) thinks key universities should turn to special English courses. Students directly receive double-language teaching after attending school. That is to say, ESP teaching should gradually become the mainstream in college English teaching of those schools. The English teaching model of some Hongkong universities prove that providing some students who have some English backgrounds with ESP courses, including using all kinds of professional classes taught by English instead of compulsory primary English can't only affect the improvement of students' English, but also improve language learning efficiency. The language learning with learning professional knowledge is the ideal language learning model[3].

1) Develop ESP(English for Special Purpose)

2) Build teaching system meeting international needs and facing working abilities

\section{Build ESP English curriculum system \\ 2. Give language requirements corresponding to ESP \\ 3. Highlight academic English teaching \\ 4. Carry out different high education teaching}

\section{REVELATION}

Firstly, we can divide ESP curriculum into two main parts: EAP (English for Academic Purpose) and EOP (English for Occupational purpose). The former includes the curriculum of class notes writing and discussing skills, thesis writing, speaking in meeting in whole English teaching. But the later includes the special English in business management, polytechnic, art, literature and medicine[4].

Chinese college English community persists, in general English teaching, to despise the existence of scientific English and the importance of ESP teaching. As Dong Yafen(1986) argues that "the feature of so-called special English is nothing 
but more long sentences, passive tense and the application of non-finite verbs. This language phenomenon frequently appears in ordinary articles". The fact is not so. Wang Zhongcang(1993) thought that English teaching mainly solves common core problems, but students' professional foreign language reading ability should be formed on this foundation. Because the forming of professional reading ability is not as easy as some people have imagined. Professional foreign language not only has its features (mastering this feature is not in one day) in vocabulary, but also has its different demands in aspects of syntax, discourse and so on. Wei xinghai, Zhou junying(1994) put out that each major has its professional idioms and vocabulary, even if the borrowed common core vocabulary has its strict definition and accurate meaning. The meaning of the same word is different from the meaning in general English, even in different subjects, the meaning is also different. Such as the meaning of solution is different in chemistry, medicine, law, math and mechanical engineering.

We can see that it is not enough to read original professional document and understand original teaching materials depending on general English (Zhang Zhenbang, 2003). Even a graduate whose English is well, has to spend a long time studying and increasing enough professional vocabulary, and gets familiar to the scientific English structure and so on. Thus he can understand English professional discourse and can be adjusted to his work. You can't imagine a student with general listening and speaking ability can successfully attend international business and technology talks, and can understand English academic lectures. You can't imagine a student with general listening and speaking ability can understand English professional articles, and can write all kinds of business letters, academic thesis and technology reports. Lu Siyan(2009) recalls that his science-andengineering students are sent to participate in foreign-involved tasks by their companies after they have graduated from school, not the graduates from foreign academies with better English. The main cause is they have learnt mathematical and other science-and-engineering ESP courses taught in English, and are familiar to the English science and technology terms on mechanic engineer and related basic knowledge. In order to actually improve international competition, satisfying with developing students' general listening, speaking, and reading abilities are more than enough. Using English to improve international competition, we must let students learn English combined with professional knowledge, that is, to improve their abilities to research and work with English.

The significance of developing ESP in universities is here. Therefore, the world's famous universities all put the key point of college English teaching on ESP courses. For example, for Asia, not only Chinese Taiwan universities, ESP teaching is also common in Japanese universities, especially Japanese top universities. Such as in Tokyo university and Kyoto university, college English is attached to major in the beginning. First grade undergraduates generally study general academic English; second to fourth grade graduates study academic English (Zhang Jihua, Gao Qin, Wang Beilei, 2009). But in universities of Hongkong, non-English teachings are basically ESP, general English is only a auxiliary curriculum. Japan and Hongkong universities not only produce lots of Nobel prize obtainers, but also are top universities recognized worldwide. Isn't the method of developing ESP teaching to improve students' international competition worth learning by us?

\section{TREND}

On one hand, college English teaching should commit to strengthen students' English language knowledge foundation, and develop students' communication ability. General English teaching uses English language knowledge teaching and English application ability as the main content. It is the main means to realize this teaching goal. Sincerely, academic English communication ability developing depends on academic English curriculum teaching, but most college graduates rarely attend academic English lectures, not to mention writing English thesis. Therefore, academic English is opened as elective course, meeting the needs of improving academic English abilities of minor students, especially graduates. On the other hand, college English teaching should introduce the history, geography, politics, literature, philosophy, art and so on to students, make students know historical view, values, view of life, aesthetic view etc. of English nations, improve the understanding of the art and difference of Chinese and foreign language culture, nation spirit and way of thinking, humanistic spirit, culture tradition and way of behavior in different history language condition, and improve humanistic quality and communication abilities across culture. To realize foreign language education humanity and the above requirements of college English teaching, the only way is to develop general English teaching and ESP teaching. In particular, general English teaching and ESP teaching not only can let students have general communication ability, but also let students have basic language tool to further study their major. Therefore, the further college English should focus on general English and academic English. ESP teaching will also be a trend of our future English teaching[5].

We believe that the enhancement of students' international competition ability lies not so much in the development of their general communicative ability as in that of their academic ability. The upsurge of English-medium-instruction course at the tertiary level and the demand for instruction in academic skills suggest that ESP is much needed by college students and is the future orientation for Chinese college English teaching[4].

In the late college English teaching developing direction, realize the status, pay attention to combine teaching reality, rich teaching methods, focus on the target of developing students' English comprehensive application ability, and make students be high-quality persons.

Liu Ling (2014) puts out that: (1) Training more graduates suitable for international purpose. From historical perspective, China more focuses on its teaching goal and quality qualifications and adjusts it continuously. Therefore, it is through the earliest focusing on grammar, later focusing on reading and last developing to focus on listening and speaking model. As the development of reforming and opening, gradually the requirement of English listening and speaking abilities is far beyond reading and writing abilities. And it raises more severe challenges of college English teaching. (2) strengthening the training of listening and speaking abilities. In 
traditional English, most of the students are dumb English. English listening and speaking abilities are the bottlenecks hindering the improvement of teaching quality. In fact, human communication are mostly inclined colloquial[6].

\section{REFERENCES}

[1] Cai Jigang.English ability obviously weaker than other countries our colleges foreign laguage teaching must transform [N].Guangming daily, 2015.
[2] Cai Jigang.our college English teaching goal locating research[J].foreign languages and their teaching,2012(3).

[3] Cai Jigang.ESP and our college teaching develop direction[J].Foreign language world, 2014 (2)

[4] Cai Jigang.The revelation of China Taiwan college ESP teaching to mainland college teaching reform[J]. foreign languages and their teaching, 2010 (6).

[5] Hu Kaibao,Xie Lixin.our college English teaching future develop orientation [J]. Foreign language world,2014(3).

[6] Liu Ling.Chinese college English teaching reform situation and developing trend analysis[J].study garden,2014 (26). 